\title{
First Report of Lymnaea columella Say, 1817 (Pulmonata: Lymnaeidae) Naturally Infected with Fasciola hepatica (Linnaeus, 1758) (Trematoda: Digenea) in Argentina
}

\section{Lucila Prepelitchi/ ${ }^{+}$, Florencia Kleiman, Silvia M Pietrokovsky, Ricardo A Moriena*, Oscar Racioppi ${ }^{*}$, José Alvarez ${ }^{*}$, Cristina Wisnivesky-Colli}

\begin{abstract}
Unidad de Ecología de Reservorios y Vectores de Parásitos, Departamento de Ecología, Genética y Evolución, Facultad de Ciencias Exactas y Naturales, Universidad de Buenos Aires, Ciudad Universitaria, Pab. II, C1428EHA, Buenos Aires, Argentina *Cátedra de Parasitología y Enfermedades Parasitarias, Universidad Nacional del Nordeste, Corrientes, Argentina

We report the first evidence of natural infection of Lymnaea columella with Fasciola hepatica in Argentina. A sample of 601 snails was collected in May 2003 in northeastern Corrientes, a province bounded on the north by Paraguay, on the east by Brazil and on the southeast by Uruguay. Among 500 examined snails, 44 (8.8\%) were exclusively infected with F. hepatica. Parasite identification was based on morphological features of cercariae from snails, and of eggs and adult flukes from Wistar rats. We discuss the events suggesting that an enzootic transmission cycle of $\mathrm{F}$. hepatica has been recently established in northeastern Corrientes.
\end{abstract}

Key words: Lymnaea columella - Fasciola hepatica infection - Argentina

Fasciolosis, caused by the zoonotic liver fluke Fasciola hepatica, is an important disease of domestic livestock producing a worldwide economic loss. Snails belonging to genus Lymnaea are the known intermediate hosts of F. hepatica. In the Southern Cone of South America, Lymnaea columella has been found in Brazil (Paraense 1982, 1983, 1986, Abilio \& Watanabe 1998, Souza et al. 1998, 2002, Oliveira et al. 2002), Paraguay (Hubendick 1951), Uruguay (Del Huerto López Lemes et al. 1996), and Argentina (Scott 1953, Castellanos \& Landoni 1981, Paraense 1982). However, the occurrence of specimens naturally infected with $F$. hepatica has only been reported from Brazil (Rezende et al. 1973, Schafranski et al. 1977, Silva Santos et al. 1987, Ueta 1980, Fujii \& Oliveira 1996, Oliveira et al. 2002, Coelho \& Lima 2003). In Uruguay, search of the parasite in L. columella rendered negative results (Del Huerto López Lemes et al. 1996) and, to our knowledge, in Paraguay and Argentina no parasitological analysis has ever been conducted.

The objective of the present study is to report the first finding of $L$. columella naturally infected with $F$. hepatica in Argentina.

A sample of 601 snails was collected in May 2003 from waterbodies within a private farm at the locality of Berón de Astrada $\left(27^{\circ} 33^{\prime} \mathrm{S} ; 57^{\circ} 32^{\prime} \mathrm{W}\right)$, in the northeast of Corrientes province, Argentina. This province is bounded on the north by Paraguay, on the east by Brazil and on the

Financial support: Agencia Nacional de Promoción Científica y Tecnológica (Proj. BID 1201 OC-AR PICT no. 08830)

${ }^{+}$Corresponding author. Fax: +54-11-4576.3384. E-mail: lucilap@bg.fcen.uba.ar

Received 28 August 2003

Accepted 25 September 2003 southeast by Uruguay. The studied area belongs to the Amazonian phytogeographic dominion, Paranense province (Cabrera \& Willink 1980). The sampling sites were temporary streams bordered on both sides by aquatic vegetation and grass. These streams, which were frequently visited by free roaming cows, collected water from a permanent lagoon. Snails were taken to the laboratory in plastic recipients holding wet cotton pads. Upon arrival, five specimens were relaxed, killed, and preserved in Railliet-Henry's fluid (Paraense 1984), and taxonomically determined by features of the shell and internal organs (Paraense 1983). The rest of the individuals, which were identical in external appearance to those already identified, were kept alive for parasitological analysis. The shell length of all snails was measured from the apex to the anterior margin. Cercarial shedding was checked for one month according to Souza et al. (2002). Preserved and alive snails were dissected to detect trematode larvae in viscera. Determination of $F$. hepatica based on morphological features of cercariae was performed under light microscope (400x). Finally, 25 metacercariae were orally administered to each of six Wistar rats 21-24 days old to confirm identity of $F$. hepatica. Search of eggs in faeces was performed from day 30 postinfection (PI) onwards and the prepatent period was recorded. After egg detection in faeces, rats were dissected for specific determination of adult flukes.

All 601 collected snails were identified as L. columella (Fig. 1). The shell length ranged between 1.90-12.00 mm with a mean \pm SD of $6.56 \pm 1.82 \mathrm{~mm}$.

In regard to infection, we examined 500 snails, of which $44(8.8 \%)$ were exclusively infected with $F$. hepatica (Fig. 2 ). The shell length of infected snails ranged between $3.79-12.00 \mathrm{~mm}$ with a mean $\pm \mathrm{SD}$ of $7.28 \pm 1.68 \mathrm{~mm}$. Twentynine out of the 44 infected snails (66\%) were included in 


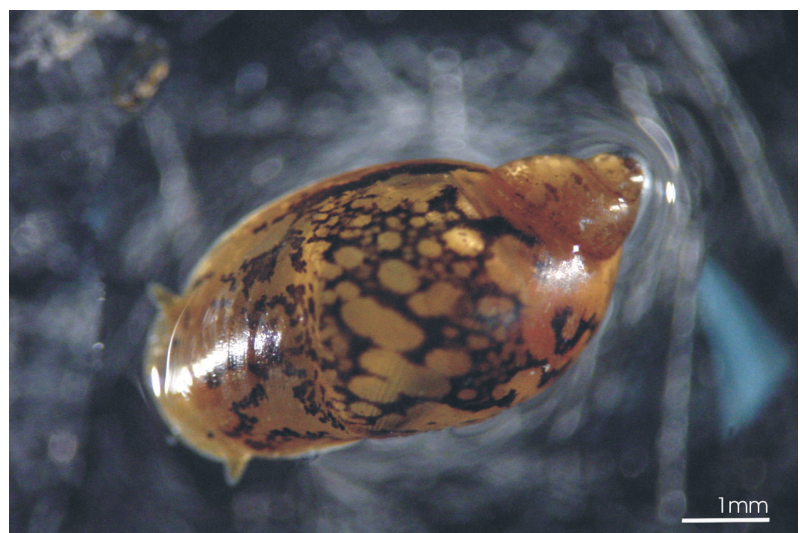

Fig. 1: Lymnaea columella from Corrientes, Argentina

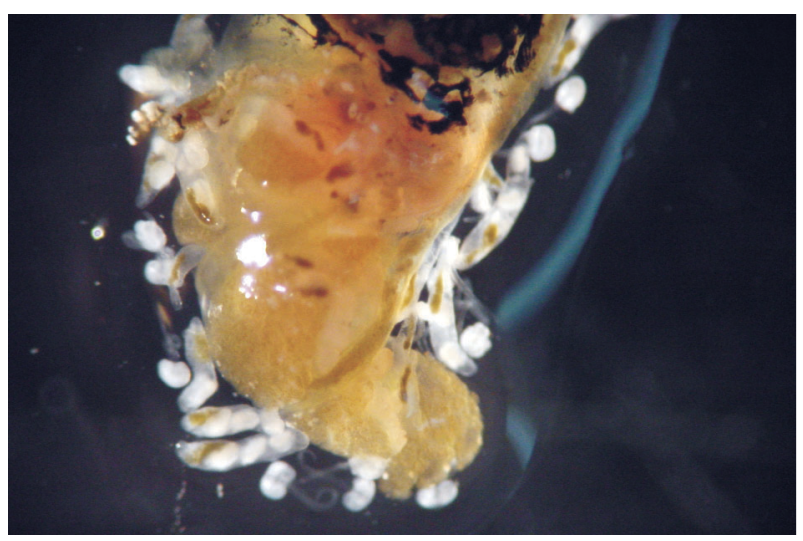

Fig. 2: rediae and cercariae of Fasciola hepatica in naturally infected Lymnaea columella from Corrientes, Argentina. 50x

the interval of 5.86-8.83 mm. Fig. 3 shows the shell length frequency distribution of dissected snails and the percentage of infection per length class.

The prepatent period of $F$. hepatica in rats was 44-49 days PI and parasite adults were found in all cases.
The first studies on the distribution, prevalence and economic impact of fasciolosis in the province of Corrientes were conducted in the 70's. At that time, the zoonosis was restricted to the central-western area (Lombardero et al. 1979b), in coincidence with the distribution of Lymnaea viatrix, which was the unique intermediate host incriminated in the parasite transmission (Lombardero et al. 1979a). Since then, new cases of fasciolosis were detected at slaughter-houses in the north of the province, as indicated by liver condemnation records (Moriena et al. 1999).

In northern Corrientes, the presence of $L$. viatrix has never been documented, while L. columella was first reported in the locality of Ituzaingó (Paraense 1982), located $82 \mathrm{~km}$ far from, and at the same latitude as Berón de Astrada. All these facts, together with the high infection rates in snails reported here, clearly show that an enzootic transmission cycle of $F$. hepatica has been established in the study area. One of the most important factors that possibly contributed to this scenario was the water-level increase in nearby Iberá marshes, after the Yacyretá dam was put into operation between 1989 and 1993. Water from the huge Yacyretá lake seeped into lower areas, covering more than 100,000 ha, specially in the department of Ituzaingó (Blanco \& Parera 2001). Flood may have increased the number of suitable snail habitats, resulting in a positive impact on L. columella populations.

The prevalence of $F$. hepatica in naturally infected $L$. columella from Corrientes (8.8\%) is higher than that recorded in the following states of Brazil: Minas Gerais (5.2\% and 3.9\%, Coelho \& Lima 2003); Rio de Janeiro (2.4\%, Rezende et al. 1973); São Paulo (1.22\% and 0.14\%, Ueta 1980; 5.26\%, Oliveira et al. 2002) and Rio Grande do Sul (3.3\%, Silva Santos et al. 1987). The last figure is particularly interesting since the province of Corrientes is partially bounded by Rio Grande do Sul.

In brief, our results indicate that $L$. columella may play an important epidemiological role in the transmission of $F$. hepatica in Northeast Argentina.

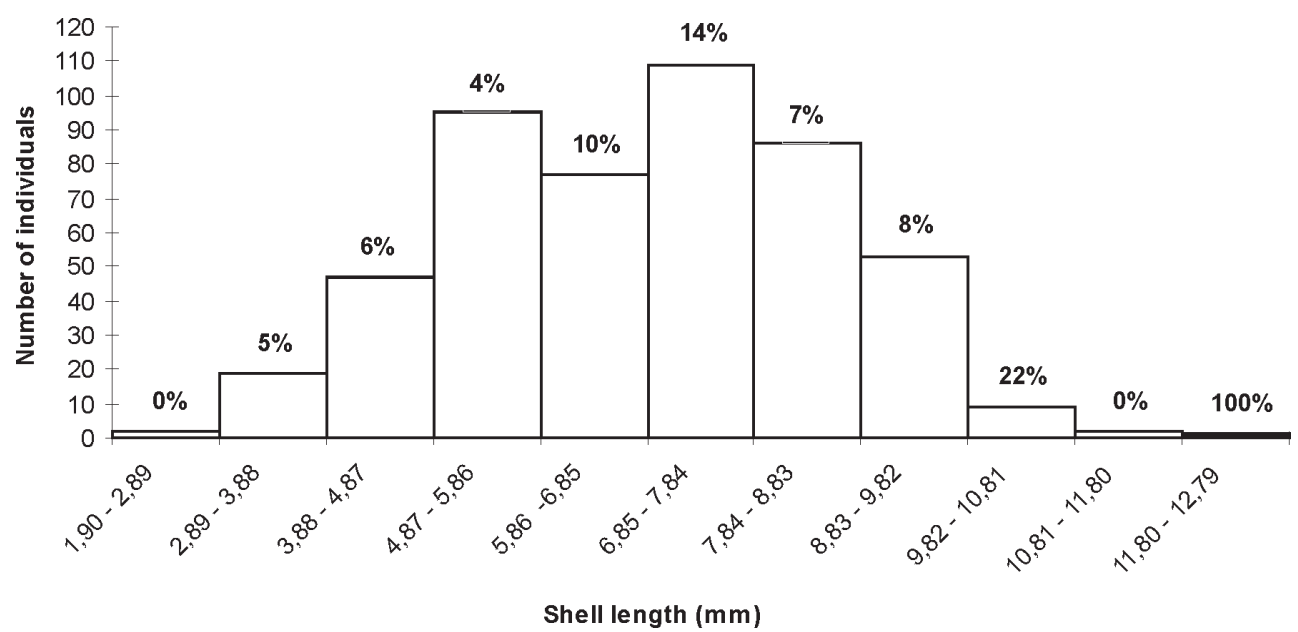

Fig. 3: shell length frequency distribution of dissected Lymnaea columella $(\mathrm{N}=500)$ from Corrientes, Argentina. The percentage of snails infected with Fasciola hepatica per length class is shown on top of each bar. 


\section{REFERENCES}

Abilio FJP, Watanabe T 1998. Ocorrência de Lymnaea columella (Gastropoda: Lymnaeidae), hospedeiro intermediário da Fasciola hepatica, para o Estado da Paraíba, Brasil. Rev Saúde Pública 32: 184-185.

Blanco D, Parera A 2001. La Inundación Silenciosa. El Aumento de las Aguas en los Esteros del Iberá: la Nueva Amenaza de la Represa Yacyretá, Fundación Vida Silvestre, Argentina, $27 \mathrm{pp}$.

Cabrera AL, Willink A 1980. Biogeografía de América Latina. In Monografía 13, Serie Biología, OEA, Washington, DC, p. 69-75.

Castellanos ZA, Landoni NA 1981. La familia Lymnaeidae Rafinesque, 1815, en la Argentina. In RA Ringuelet, Fauna de Agua Dulce de la República Argentina, Profadu, Conicet, Buenos Aires, p. 55-82.

Coelho LHL, Lima WS 2003. Population dynamics of Lymnaea columella and its natural infection by Fasciola hepatica in the state of Minas Gerais, Brazil. J Helminthol 77: 7-10.

Del Huerto López Lemes M, Hernández S, Acuña AM, Nari A 1996. Fascioliasis en la República Oriental del Uruguay. Congreso Latinoamericano de Parasitología, Santiago de Chile. Website: http://www.smu.org.uy/publicaciones/rmu/ 1996v1/lopez.htm/b1

Fujii TU, Oliveira SM 1996. Ocorrência de caramujos Lymnaea columella naturalmente infectados por Fasciola hepatica, no município de Miracatu, Vale do Ribeira, SP. Resultados preliminares. Jornada Paulista de Parasitologia, São Paulo, p. 17.

Hubendick B 1951. Recent Lymnaeidae: their variation, morphology, taxonomy, nomenclature, and distribution. Kungl Svensk Vetenskaps Handl 3: 1-223.

Lombardero O, Moriena R, Racioppi O, Quiroz L 1979a. Binomia de Limnaea sp. en la provincia de Corrientes. Veterinaria (Corrientes, Argentina) 2: 5-19.

Lombardero O, Moriena R, Racioppi O, Coppo JA, Schiffo HP 1979b. Distomatosis hepática de los bovinos en la provincia de Corrientes. Veterinaria (Corrientes, Argentina) 2: 21-29.

Moriena R, Racioppi O, Alvarez JD, Lombardero OJ 1999. Fasciola hepatica y otros trematodes de los rumiantes. Prevalencia y distribución en la provincia de Corrientes (Estado de Avance). Comunicaciones científicas y tecnológicas de la Universidad Nacional del Nordeste (Argentina), Website: http://www.unne.edu.ar/cyt/cyt2000.htm

Oliveira SM, Fujii TU, Sposito Filha E, Martins AMCRPF 2002. Ocorrência de Lymnaea columella Say, 1817 infectada naturalmente por Fasciola hepatica (Linnaeus, 1758), no Vale do Ribeira, São Paulo, Brasil. Arq Inst Biológico 69: 29-37.

Paraense WL 1982. Lymnaea viatrix and Lymnaea columella in the Neotropical region: a distributional outline. Mem Inst Oswaldo Cruz 77: 181-188.

Paraense WL 1983. Lymnaea columella in Northern Brazil. Mem Inst Oswaldo Cruz 78: 477-482.

Paraense WL 1984. Lymnaea diaphana: a study of topotypic specimens (Pulmonata: Lymnaeidae). Mem Inst Oswaldo Cruz 79: 75-81.

Paraense WL 1986. Lymnaea columella: two Brazilian localities in the states of Amazonas and Bahia. Mem Inst Oswaldo Cruz 81: 121-123.

Rezende HEB, Araújo JL, Gomes PAC, Nurenberg S, Neto MP, Oliveira GP, Mello RP 1973. Notas sobre duas espécies de Lymnaea Lamark, 1799, hospedeiros intermediários de Fasciola hepatica L. no estado do Rio de Janeiro (Mollusca, Gastropoda, Basommatophora, Lymmaeidae). Arq Univ Fed Rural 3: 21-23.

Schafranski NL, Vianna SSS, Saber AF 1977. Levantamento de focus de Fasciola hepatica Linnaeus, 1758, no Vale do Paraíba, estado de São Paulo; encontro de Lymnaea columella Say, 1817, naturalmente infectada. Conferencia Anual da Sociedade Paulista de Medicina Veterinaria, p. 103 .

Scott MIH 1953. Sobre Limnaeidae argentinos. Physis 20: 401408.

Silva Santos IC, Laranja RJ, Costa NC, Bothelo GA, Ceresér VH, Martins JR 1987. Lymnaea columella Say, 1817 interagindo na disseminação de fasciolose na Estação Experimental Zootécnica de Dom Pedrito, RS. Hora Veterinária 6: 42-48.

Souza CP, Lima LC, Jannotti-Passos LK, Silva Ferreira S, Guimarães CT, Belo de Figuereido Viela L, Mariani Junior R 1998. Moluscos límnicos da microrregião de Belo Horizonte, MG, com ênfase nos vetores de parasitos. Rev Soc Bras Med Trop 31: 449-456.

Souza CP, Magalhães KG, Jannotti Passos LK, Pereira do Santos GC, Ribeiro F, Katz N 2002. Aspects of the maintenance of the life cycle of Fasciola hepatica in Lymnaea columella in Minas Gerais, Brazil. Mem Inst Oswaldo Cruz 97: 407-410.

Ueta MT 1980. Ocorrência de infecção natural de Fasciola hepatica Linnaeus, 1758 em Lymnaea columella Say, 1817 no vale do Paraíba, SP, Brasil. Rev Saúde Pública 14: 230233. 